\title{
ANALISIS PENGARUH KINERJA LINGKUNGAN DAN KINERJA KEUANGAN TERHADAP PENGUNGKAPAN LAPORAN KEBERLANJUTAN PADA PERUSAHAAN NONKEUANGAN YANG TERDAFTAR DI BURSA EFEK INDONESIA
}

\author{
Tusiyati \\ Universitas Bina Nusantara \\ tusiyati60@gmail.com
}

\begin{abstract}
This study aimed to determine the impact of environmental performance measured by PROPER (Program Penilaian Peringkat Kinerja Perusahaan dalam Pengelolaan Lingkungan Hidup) and financial performance on disclosure of sustainability report. Sustainability Report (SR) measured by 46 items disclosure stated on G4 GRI (2013), while financial performance measured by using ratio of profitability, liquidity, and leverage of non-financial companies listed in Indonesian Stock Exchange and located in DKI Jakarta. A stastistical method used in this study is multiple regression analysis to examine the effect of environmental performance on the disclosure of sustainability report. Data analysis and hypothesis testing in this study using SPSS version 20. Results showed: (1) environmental performance the company has a significant positive effect on the disclosure of sustainability report, (2) financial performance has a significant negative effect on the disclosure of sustainability report.
\end{abstract}

Keywords: Global Reporting Initiative, Sustainability Report, Environmental Performance, Financial Performance

\section{PENDAHULUAN}

Pada masa sekarang ini perusahaan tidak hanya diwajibkan membuat laporan keuangan yang sesuai dengan standar tetapi juga harus memperhatikan biaya lingkungan, seperti biaya pengolahan limbah untuk perusahaan industri, biaya perbaikan lingkungan untuk perusahaan pertambangan dan biaya- biaya lainnya yang berkaitan dengan lingkungan. Perusahaan tidak hanya mementingkan kegiatan untuk mendapatkan laba sebanyakbanyaknya (profit oriented), namun perusahaan juga dituntut untuk berpartisipasi aktif dalam pengelolaan lingkungan dan memperhatikan kesejahteraan masyarakat. Kementrian Negara 
Lingkungan Hidup Indonesia telah membuat peraturan no 06 tahun 2013 tentang Program Penilaian Peringkat Kinerja Perusahaan dalam Pengelolaan Lingkungan Hidup (PROPER). PROPER merupakan salah satu upaya Kementrian Negara Lingkungan Hidup untuk mendorong penataan perusahaan dalam pengelolaan lingkungan hidup pada instrumen informal. Program tersebut dilakukan melalui berbagai kegiatan yang diarahkan untuk mendorong perusahaan dalam mematuhi peraturan perundangundangan dan mendorong perusahaan yang sudah baik kinerja lingkungannya untuk menerapkan produksi bersih. Dasar hukum PROPER adalah Keputusan Menteri Negara Lingkungan Hidup No 127/MENLH/2002 menyatakan bahwa PROPER mencakup pengendalian pencemaran air, udara, dan pengelolaan limbah Bahan Berbahaya Beracun (B3). Permasalahan lingkungan hidup merupakan tanggung jawab sosial perusahaan atau yang di sebut sebagai Corporate Social Responsibility (CSR). Kesadaran masyarakat saat ini menilai sebuah bisnis atau perusahaan tidak hanya dari kualitas produknya, tetapi juga menilai dari sisi tanggung jawab sosial yang dijalankan perusahaan tersebut. Dengan ini, organisasi tidak lagi soal menciptakan nilai tambah sebuah produk untuk memenuhi kebutuhan masyarakat, tetapi juga berkaitan dengan bagaimana kreativitas dalam mencerminkan komitmen bisnis terhadap isu-isu sosial termasuk lingkungan yang menjadi perhatian masyarakat dan konsumennya secara khusus. Corporate Social Responsibility adalah komitmen usaha untuk bertindak secara etis, beroperasi secara legal, dan berkontribusi untuk peningkatan ekonomi bersamaan dengan peningkatan kualitas hidup karyawan dan keluarganya, komunitas lokal, dan masyarakat yang lebih luas menurut Trinidads \& Tobacco Bureau of Standards (Reza, 2009:10). Konsep Corporate Social Responsibility berfokus pada triple bottom line yaitu economic prosperity, environment quality dan social justice. Perusahaan dapat terus melanjutkan kegiatan usahanya dengan mengimplementasikan konsep triple bottom line ke dalam 
tiga aspek, yaitu keuntungan (profit), terlibat pada pemenuhan kesejahteraan masyarakat (people) dan menjaga kelestarian lingkungan (planet). Perusahaan dalam mengungkapkan sebuah tindakan pertanggungjawaban sosial yang telah dilakukan kepada stakeholders dalam sustainability report (laporan keberlanjutan). Sebuah laporan keberlanjutan pada perusahaan memberikan gambaran yang seimbang dan wajar terhadap kinerja keberlanjutan dari organisasi atau perusahaan pelapor, termasuk kontribusi positif dan negatif yang telah mereka lakukan dalam periode tertentu" (Nurani Sari, 2014:528). Pelaporan berkelanjutan membantu organisasi untuk menetapkan tujuan, mengukur kinerja, dan mengelola perubahan dalam rangka membuat operasi mereka lebih berkelanjutan.

Sebuah laporan berkelanjutan mengungkapkan dampak organisasi baik positif maupun negatif terhadap lingkungan, masyarakat dan ekonomi. Laporan berkelanjutan sangat penting bagi perusahaan dalam mempertanggung jawabkan bisnisnya, tidak hanya kepada pemegang saham tetapi juga kepada publik yang berkaitan dengan kepedulian sosial dan pelestarian lingkungan serta dapat menarik minat investor agar mau berinvestasi. Tren pada saat ini investor tidak hanya melihat laporan kinerja saja, tetapi bagaimana perusahaan dapat menjaga keberlangsungan bisnisnya dimasa depan. Sustainability Report di terapkan di Indonesia sejak tahun 2000 dan pedoman yang digunakan adalah GRI sebagai referensi perusahaan untuk menyusun laporan keberlanjutan. Selain untuk meningkatkan citra perusahaan diharapkan sustainability report juga memiliki pengaruh yang signifikan terhadap kinerja lingkungan, tingkat profitabilitas, tingkat likuiditas dan tingkat leverage perusahaan. Berdasarkan penelitian Aggarwal Priyanka (2015) Sustainability Reporting and its Impact on Corporate Financial: Literatur Review mengungkapkan bahwa "kinerja keuangan memberikan pengaruh yang signifikan terhadap laporan keberlanjutan". Laporan berkelanjutan meningkatkan reputasi 
perusahaan dan kinerja keuangan karena menghasilkan berbagai sinergi dan manfaat yang diperoleh perusahaan dalam pelaporan. Berdasarkan latar belakang masalah tersebut maka penelitian ini

\section{TELAAH LITERATUR}

Global Reporting Initiative (GRI, 2011) mendefinisikan sustainability sebagai praktek pengukuran, pengungkapan, dan juga sebagai pertanggungjawaban kepada pemangku kepentingan internal dan eksternal untuk kinerja organisasi dalam mencapai tujuan pembangunan keberlanjutan. Para analis keuangan, investor, dan pemangku kepentingan lainnya semakin menuntut informasi keuangan seperti lingkungan sosial dan pemerintahan, kinerja non perusahaan atas informasi keuangan sehingga dapat mengambil keputusan investasi yang lebih rasional. GRI didirikan di Boston, Amerika Serikat pada tahun 1997 oleh organisasi non-profit Amerika Serikat koalisi ekonomi dan tanggung jawab lingkungan (CERES), Tellus Institute dan United mengambil judul analisis pengaruh kinerja lingkungan dan kinerja terhadap pengungkapan laporan keberlanjutan pada perusahaan non keuangan yang terdaftar di bursa efek Indonesia 2011-2013.

Nations Environment Programme (UNEP). Tujuannya adalah untuk membuat mekanisme akuntabilitas tanggung jawab lingkungan sesuai prinsip CERES. GRI-G1 dikeluarkan pada tahun 2000 yang merupakan kerangka pedoman global yang pertama untuk pelaporan keberlanjutan yang komprehensif. GRI-G2 diresmikan pada tahun 2002, pada KTT dunia tentang pembangunan berkelanjutan di Johannesburg. GRI-G3 terus dikembangkan karena banyak permintaan untuk bimbingan pelaporan GRI. GRI terus memperluas strategi dan framework pelaporan. GRI-G3 mulai digunakan pada tahun 2006. Pedoman GRI merupakan kerangka pelaporan yang direkomendasikan bagi perusahaan untuk mengkomunikasikan tentang kemajuan dan proses berkelanjutan perusahaan. Pada Agustus 2010 GRI dan Price of Wales Accounting 
Project Sustainability yang nantinya mengumunmkan pembentukan International Intergrated Reporting Comite (IIRC) yang bertujuan untuk mengembangkan kerangka kerja yang menyatukan informasi keuangan, lingkungan, sosial dan tata kelola secara jelas, konsisten, sebanding dan terintegrasi. GRI-G4 digunakan pada tahun 2013, GRI-G4 menyediakan panduan mengenai bagaimana cara menyajikan pengungkapan keberlanjutan dalam format yang berbeda dengan GRI sebelumnya: baik itu laporan keberlanjutan mandiri, laporan terpadu, laporan tahunan, laporan yang membahas norma-norma internasional tertentu, atau pelaporan online. GRI-G4 dirancang agar dapat diterapkan secara universal untuk semua organisasi, besar dan kecil, di seluruh dunia. Fitur yang ada di GRI-G4 menjadikan pedoman ini lebih mudah digunakan, baik bagi pelapor yang berpengalaman dan bagi mereka yang baru dalam pelaporan untuk keberlanjutan. Sustainability report merupakan jenis laporan perusahaan yang menyampaikan sebuah informasi keberlanjutan yang berkaitan dengan dampak ekonomi, lingkungan, dan sosial dalam kegiatan produksi dengan cara yang sebanding dengan pelaporan keuangan. Laporan keberlanjutan juga menyajikan nilainilai dan tata kelola model organisasi yang menunjukkan hubungan antara strategi dan komitmennya dalam ekonomi global yang berkelanjutan.

Standar Pengungkapan dalam Sustainability Report

Menurut GRI-G4 Guideliness standar pengungkapan dalam sustainability report terdiri dari Standar Pengungkapan Umum di mana meliputi:

a. Strategi \& analisis yang memberikan gambaran umum tentang keberlanjutan organisasi, untuk memberikan konteks pada laporan selanjutnya yang lebih detail dibandingkan dalam pedoman.

b. Profil organisasi merupakan gambaran keseluruhan mengenai karakteristik organisasi, untuk memberikan konteks bagi 


$$
\begin{aligned}
& \text { rician dalam laporan } \\
& \text { dibandingkan dengan bagian } \\
& \text { yang ada dalam laporan. } \\
& \text { c. Aspek material } \\
& \text { memberikan gambaran } \\
& \text { keseluruhan tentang proses } \\
& \text { yang telah diikuti oleh } \\
& \text { organisasi untuk } \\
& \text { menentukan konten } \\
& \text { laporan, aspek material } \\
& \text { dan boundary, serta } \\
& \text { pernyataan ulang. }
\end{aligned}
$$

d. Hubungan stakeholders merupakan gambaran keseluruhan tentang hubungan dengan pemangku kepentingan organisasi selama periode pelaporan dan tidak hanya terbatas pada keterlibatan yang dilakukan untuk tujuan penyusunan laporan.

e. Profil laporan menyajikan gambaran keseluruhan tentang informasi dasar mengenai laporan, indeks konten GRI, dan pendekatan untuk memperoleh assurance eksternal. f. Tata kelola memberikan gambaran keseluruhan tentang struktur tata kelola dan komposisinya, peran badan tata kelola tertinggi dalam menetapkan tujuan, nilai dan strategi organisasi, kompetensi dan evaluasi kinerja badan tata kelola tertinggi, peran badan tata kelola tertinggi dalam manajemen resiko, pelaporan berkelanjutan, dan dalam mengevaluasi kinerja ekonomi, lingkungan dan sosial, serta renumerasi dan insentif.

g. Etika dan integritas merupakan gambaran keseluruhan tentang nilai, prinsip dan norma di organisasi, mekanisme internal dan eksternal untuk memperoleh masukan mengenai perilaku etis dan taat hukum serta untuk melaporkan permasalahan tentang perilaku yang tidak etis atau melanggar hukum. 
Corporate Social Responsibility (CSR)

\section{Corporate Social Responsibility} adalah tanggung jawab perusahaan kepada stakeholders dalam berbagai aspek operasional perusahaan mulai dari pelanggan, pemasok, klien, pemegang saham, karyawan, media, masyarakat, hingga pemerintah dan lingkungan (Rosinta dan Holly, 2012). Menurut Trinidads \& Tobacco Bureau of Standards, Corporate Social Responsibility adalah komitmen usaha untuk bertindak secara etis, beroperasi secara legal, dan berkontribusi untuk peningkatan ekonomi bersamaan dengan peningkatan kualitas hidup karyawan dan keluarganya, komunitas lokal, dan masyarakat yang lebih luas (Reza, 2009).

Corporate Social Responsibility di Indonesia

Di Indonesia Corporate Social Responsibilities (CSR) telah diwajibkan melalui undang-undang No. 40 Tahun 2007 tentang perseroan terbatas. Melalui pasal 74 dari undang-undang ini setiap perseroan terbatas diwajibkan untuk menerapkan CSR. Awal ditetapkan undang-undang tersebut, perusahaan merasa pelaksaanaan CSR hanya menambah beban pengeluaran kas perusahaan, karena hal tersebut dianggap tidak memberikan manfaat bagi perusahaan. Sehingga pelaksanaan CSR hanya didasarkan atas kepatuhan untuk memenuhi hukum yang berlaku. Namun dewasa ini banyak perusahaan melaksanaan CSR bukan sekedar bertujuan untuk patuh terhadap hukum sehingga tidak mendapatkan hukuman, melainkan telah menyadari dan merasakan manfaat yang positif dari pelaksaanaan CSR. Jadi, ada atau pun tidak ada undang-undang untuk melaksanaan CSR, perusahaan dewasa ini tetap akan menjalankan CSR tersebut. Undang-Undang Nomor 40 Tahun 2007 Pasal 74 ayat 1- 4, berbunyi antara lain:

1. Perseroan yang menjalankan kegiatan usahanya di bidang dan/atau berkaitan dengan sumber daya alam wajib melaksanakan tanggung jawab sosial dan lingkungan. 
2. Tanggung Jawab Sosial dan lingkungan sebagaimana yang dimaksud pada ayat (1) merupakan kewajiban Perseroan yang dianggarkan dan diperhitungkan sebagai biaya perseroan yang pelaksanaannya dilakukan dengan memperhatikan kepatuhan dan kewajaran.

3. Perseroan yang tidak melaksanakan kewajiban sebagaimana dimaksud pada ayat (1) dikenai sanksi sesuai dengan ketentuan peraturan perundang-undangan.

4. Ketentuan lebih lanjut mengenai Tanggung Jawab Sosial dan Lingkungan diatur dengan Peraturan Pemerintah.

Peraturan pemerintah No 47 Tahun 2012 pada bagian penjelasan di pasal 2 yaitu ketentuan ini menegaskan bahwa pada dasarnya setiap Perseroan sebagai wujud kegiatan manusia dalam bidang usaha, secara moral mempunyai komitmen untuk bertanggung jawab atas tetap terciptanya hubungan perseroan yang serasi dan seimbang dengan lingkungan dan masyarakat setempat sesuai dengan nilai, norma, dan budaya masyarakat tersebut. Undang-Undang nomor 25 tahun 2007 tentang penanaman modal dalam Pasal 15, setiap penanam modal berkewajiban untuk:

1. Menerapkan prinsip tata kelola perusahaan yang baik.

2. Melaksanakan tanggung jawab sosial perusahaan.

3. Membuat laporan tentang kegiatan penanaman modal dan menyampaikannya kepada Badan Koordinasi Penanaman Modal.

4. Menghormati tradisi budaya masyarakat sekitar lokasi kegiatan usaha penanaman modal.

5. Mematuhi semua ketentuan peraturan perundang-undangan. 
Pasal 17 berbunyi "Penanam modal yang mengusahakan sumber daya alam yang tidak terbarukan wajib mengalokasikan dana secara bertahap untuk pemulihan lokasi yang memenuhi standar kelayakan lingkungan hidup, yang pelaksanaannya diatur sesuai dengan ketentuan peraturan perundangundangan". International Corporate Social Responsibility CSR tertuang dalam ISO 26000 (International Organization for Standardization), ISO 26000 menyediakan standar pedoman mengenai tanggung tanggung jawab sosial suatu institusi yang mencakup semua sektor badan publik ataupun badan privat baik di negara berkembang maupun negara maju. Berdasarkan konsep ISO 26000, penerapan sosial responsibility hendaknya terintegrasi di seluruh aktivitas organisasi yang mencakup 7 isu pokok yaitu pengembangan masyarakat, konsumen, praktek kegiatan institusi yang sehat, lingkungan, ketenagakerjaan, hak asasi manusia dan organizational governance (tata kelola organisasi). ISO 26000 menerjemahkan tanggung jawab sosial sebagai tanggung jawab suatu organisasi atas dampak dari keputusan dan aktivitasnya terhadap masyarakat dan lingkungan, melalui perilaku yang transparan dan etis, yang konsisten dengan pembangunan berkelanjutan dan kesejahteraan masyarakat, memperhatikan kepentingan para stakeholder, sesuai hukum yang berlaku dan konsisten dengan norma-norma internasional, dan terintegrasi di seluruh aktivitas organisasi, dalam pengertian ini meliputi baik kegiatan, produk maupun jasa. Amerika Serikat memiliki peraturan tentang CSR yang disebut Chicago Climate Exchange adalah satu-satunya system perdagangan untuk enam green house gases (GHGs) di Amerika Utara. Para anggotanya berkomitmen secara sukarela tapi mengikat secara hukum untuk memenuhi target pengurangan gas rumah kaca tahunan (Doupnik dan Perera, 2012:751). Menurut Doupnik dan Perera (2012:759) produk yang diungkapkan dan metode pengungkapan CSR berbeda-beda diberbagai negara, misalnya: 
1. Amerika Serikat, Inggris, dan Australia mengungkapkan sebagian besar sumber daya manusia dan keterlibatan masyarakat. Metode pengungkapan di Amerika Serikat dan Inggris mengungkapkan secara jelas tentang pengungkapan keuangan dan nonkeuangan, sedangkan di Australia terbatas pada kuantifikasi nonkeuangan dan metode pengungkapan CSR sesuai dengan yang menguntungkan bagi perusahaan yang bersangkutan, selalu meningkatkan pengungkapan yang positif walaupun kebenarannya adalah negatif. Perusahaan di Australia belum mengadopsi standar pelaporan untuk stakeholders, laporan CSR yang bersertifikat dikeluarkan oleh auditor independen.

2. Thailand sebagian besar mengungkapkan tentang karyawan dan informasi lingkungan.
3. Perusahaan dari Negaranegara yang meratifikasi Protocol Kyoto (Eropa dan Jepang) tampaknya memiliki indeks pengungkapan yang lebih tinggi berkaitan dengan polusi dan emisi gas rumah kaca.

4. Jepang merupakan Negara yang mengungkapkan dalam tingkat yang tinggi tentang perubahan iklim.

Secara global, Asosiasi Chartered Certified Accountants (ACCA) memegang penghargaan yang diakui secara internasional untuk pelaporan keberlanjutan dan mengacu pada pedoman GRI dalam menganalisis laporan keberlanjutan.

Kinerja Keuangan

Penilaian yang paling utama digunakan untuk menilai kinerja sebuah perusahaan adalah dengan melihat sisi kinerja keuangan dan kinerja non keuangan. Kinerja keuangan adalah suatu analisis yang dilakukan untuk melihat sejauh mana suatu perusahaan telah melaksanakan dengan menggunakan aturan-aturan pelaksanaan keuangan secara baik dan benar dan sesuai 
standar yang berlaku. Perhitungan rasio-rasio keuangan yang sering digunakan untuk mengetahui bagaimana kinerja keuangan perusahaan yaitu dengan rasio profitabilitas, leverage keuangan, rasio likuiditas, dan rasio aktivitas.

Profitabilitas

Profitabilitas digunakan untuk menunjukkan keberhasilan perusahaan dalam menghasilkan keuntungan. Rasio profitabilitas bertujuan untuk mengukur efisiensi penggunaan aktiva perusahaan dan mengukur efektivitas manajemen dilihat dari laba yang dihasilkan terhadap penjualan dan investasi. Secara keseluruhan rasio ini mengukur efektifitas manajemen secara keseluruhan yang ditunjukkan oleh besar kecilnya tingkat keuntungan yang diperoleh dalam hubungannya dengan penjualan maupun investasi. Semakin baik rasio profitabilitas maka semakin baik menggambarkan kemampuan tingginya perolehan keuntungan perusahaan.
Likuiditas

Rasio likuiditas mengukur kemampuan perusahaan dalam memenuhi kewajiban jangka pendeknya. Rasio likuiditas sangat penting karena kegagalan dalam membayar kewajiban dapat menyebabkan kebangkrutan perusahaan. Rasio ini mengukur pada kemampuan likuiditas jangka pendek perusahaan dengan melihat aktiva lancar perusahaan relatif terhadap hutang lancarnya (kewajiban perusahaan). Menurut Irham Fahmi (2013) secara umum ada dua rasio likuiditas yaitu current rasio merupakan ukuran yang umum digunakan atas solvensi jangka pendek, kemampuan perusahaan memenuhi kebutuhan utang ketika jatuh tempo dan quick rasio adalah ukuran uji solvensi jangka pendek yang lebih teliti dari pada rasio lancar karena pembilangnya mengeliminasi persediaan yang di anggap aktiva lancar yang sedikit tidak likuid dan kemungkinan menjadi sumber kerugian. 
Leverage

Rasio leverage digunakan untuk mengukur seberapa besar perusahaan dibiayai dengan utang. Penggunaan hutang yang terlalu tinggi akan membahayakan perusahaan karena dapat menyebabkan perusahaan termasuk kesalam kategori extreme leverage (perusahaan terjebak dalam hutang yang banyak) dan sulit untuk melepaskan beban hutang tersebut. "Perusahaan seharusnya mampu menyeimbangkan antara beberapa hutang yang layak untuk diambil dan dari mana sumber-sumber yang akan dipakai untuk membayar hutang" Irham, (2013).

\section{Kinerja Lingkungan}

Biaya lingkungan adalah biaya yang ditimbulkan akibat adanya kualitas lingkungan yang rendah sebagai akibat dari proses produksi yang dilakukan oleh perusahaan seperti biaya pengolahan limbah, pengendalian pencemaran (air, udara dan tanah) dan efek sosial pada masyarakat sekitar. Biaya lingkungan harus dilaporkan secara terpisah berdasarkan klasifikasi biayanya supaya laporan biaya lingkungan dapat dijadikan informasi yang berguna untuk mengevaluasi kinerja operasional perusahaan terutama yang berdampak pada lingkungan. Belum ada standar baku untuk nama akun biaya lingkungan, sehingga setiap perusahaan akunnya berbeda, biaya lingkungan yang terjadi disajikan dalam akun khusus atau dalam sub-biaya administrasi dan umum, pada perusahaan manufaktur memasukkan akun tersebut kedalam overhead. Kinerja lingkungan adalah hubungan antara perusahaan dan lingkungan, termasuk dampak lingkungan dari sumber daya yang di konsumsi, dampak dari proses organisasi, implikasi dari produk dan jasa, pemulihan dan pengolahan produk serta memenuhi persyaratan hukum (http://www.epaw.co.uk) ( Bambang, 2013).Salah satu metode dalam mengukur kinerja lingkungan di seluruh Negara adalah Environmental Performance Index (EPI), Indeks ini diperkenalkan pada tahun 2002 yang dikembangkan untuk mendukung pencapaian tujuan pembangunan terutama dalam aspek lingkungan. Pada tahun 2014 indonesia menempati urutan 112 dari 178 negara yang berpartisipasi dalam program tersebut (epi.yale.edu/epi). 
Di Indonesia Program Penilaian

Peringkat Kinerja Perusahaan dalam Pengelolaan Lingkungan (PROPER) telah dilakukan sejak tahun 2002 oleh Kantor kementrian Lingkungan Hidup sebagai pengembangan dari program PROKASIH (Program Kali Bersih) pada tahun 1995. "PROPER merupakan perwujudan transparasi, demokrasi dalam pengelolaan lingkungan alam Indonesia sehingga tercapai Good Governance di tiap perusahaan yang ikut serta dalam PROPER” (Kartika， 2014:619). Kriteria penilaian PROPER berdasarkan aspek sistem manajemen lingkungan, pemanfaatan

\section{PEMBAHASAN}

Untuk membahas dalam penelitian tersebut, penulis untuk penelitian ini menggunakan data-data dari perusahaan non keuangan antara lain yang mengikuti PROPER, go public, dan berada di DKI wilayah Jakarta pada tahun 2011 sampai di tahun 2013. Dari total semua sebanyak 70 perusahaan nonkeuangan yang sumber daya (efisiensi energi, pengurangan dan pemanfaatan limbah bahan berbahaya dan beracun, Reduce, Reuse, dan Recycle (3R) limbah padat non bahan berbahaya dan beracun, pengurangan pencemar udara, konservasi dan penurunan beban pencemaran air, dan perlindungan keanekaragaman hayati), pemberdayaan masyarakat, dan penyusunan dokumen ringkasan kinerja pengelolaan lingkungan. Penilaian hasil kinerja PROPER untuk perusahaan dilambangkan dengan 5 warna yaitu emas, hijau, biru, merah dan hitam.

mengikuti PROPER di DKI Jakarta hanya sebesar 11 perusahaan yang terdaftar dalam Bursa Efek Indonesia (go public). Dari hasil penelitian yang dilakukan oleh penulis di mana menggunakan statistik deskriptif, sehingga dalam penelitian ini menghasilkan gambaran data antara lain sebagai berikut. 
Tabel 1 Descriptive Statistics

\begin{tabular}{cccccc} 
& N & Minimum & Maximum & Mean & $\begin{array}{c}\text { Std. } \\
\text { Deviation }\end{array}$ \\
SRD & 33 & .00 & .80 & .5797 & .18250 \\
PPP & 33 & .20 & .80 & .5758 & .13926 \\
ROA & 33 & -.02 & .19 & .0894 & .05147 \\
CURRENT & 33 & .83 & 10.64 & 2.9125 & 2.06565 \\
DER & 33 & .16 & 1.73 & .6119 & .40846 \\
Valid N & 33 & & & & \\
(listwise) & & & & & \\
\hline
\end{tabular}

Jumlah data yang digunakan $(\mathrm{N})$ adalah 33 data yang merupakan data dari tahun 2011 hingga 2013 dari 11 perusahaan yang mengikuti PROPER, go public dan berada di DKI Jakarta. Pengungkapan laporan keberlanjutan (SRD) yang diukur berdasarkan jumlah pengungkapan laporan keberlanjutan atau pengungkapan laporan tahunan terhadap jumlah pengungkapan aspek GRI 4 memiliki nilai rata-rata 0.5797 dengan standar deviasi 0.18250. Nilai paling tinggi untuk perusahaan yang melaporkan laporan keberlanjutan adalah $0.80 \quad(80 \%)$, sedangkan ada perusahaan yang tidak melaporkan laporan keberlanjutan dengan nilai minimum 0.00 (0\%). Kinerja lingkungan diukur berdasarkan penilaian PROPER (PPP) dengan nilai ratarata 0.5797 dan standar deviasi 0.13926 menunjukkan bahwa sebagian besar perusahaan non keuangan yang berada di DKI Jakarta memiliki kinerja lingkungan yang baik. Profitabilitas merupakan salah satu indikator dari kinerja keuangan yang diukur berdasarkan Return On Asset (ROA) dengan nilai terendah -0.2 dan nilai tertinggi 0.19 memiliki nilai rata-rata 0.0894 dan standar deviasi 0.5147. Indikator kinerja keuangan yang kedua adalah likuiditas yang menggunakan Current Ratio (CURRENT) dengan cakupan nilai 0.83 hingga 10.64 memiliki nilai rata-rata 2.9125 dan standar deviasi 2.06565. Leverage merupakan indikator kinerja keuangan yang terakhir dengan Debt To Equity Ratio (DER) dengan cakupan nilai 0.16 hingga 1.73 memiliki nilai rata-rata 0.6119 dan standar deviasi 0.40846 . 
Uji Asumsi Klasik

Uji asumsi klasik bertujuan mengetahui hubungan antar variabel penelitian yang ada dalam model regresi. Model regresi dikatakan baik jika data terdistribusi secara normal, tidak mengandung multikoliniearitas, heteroskedastisitas dan autokorelasi.

Uji Normalitas

Uji normalitas bertujuan untuk mengetahui apakah nilai residual yang dihasilkan dari regresi terdistribusi secara normal atau tidak. Model regresi yang baik adalah yang memiliki nilai residu yang terdistribusi secara normal.

One Sample Kolmogorov-Smirnov Test

Uji one sample kolomogorov smirnov bertujuan untuk mengetahui distribusi data, apakah mengikuti distribusi normal, poissson, uniform atau exponential. Dalam penelitian ini uji one sample kolomogorov smirnov digunakan untuk mengetahui apakah distribusi residual terdistribusi secara normal atau tidak.

Tabel 2 Unstandardized Residual

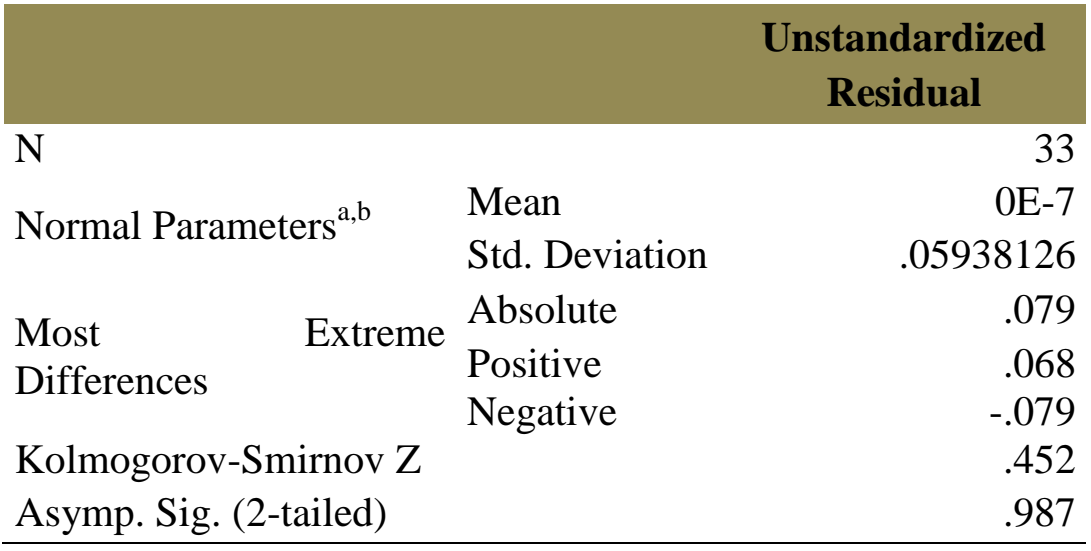

Dari table 4.2 nilai kolmogrovSmirnov Z sebesar 0.452 dan nilai probabilitas signifikansi (Asymp. Sig. 2-tailed) sebesar 0.987. Karena nilai signifikansi lebih dari 0.05
(0.987>0.05), maka nilai residualnya normal atau data terdistribusi secara normal. Data dikatakan tidak normal jika memiliki nilai signifikansi kurang dari 0.05 (Asymp.Sig < 0.05). 
Tabel 3 Coefficients

\begin{tabular}{lrrrrrr} 
Model & \multicolumn{2}{c}{$\begin{array}{c}\text { Unstandardized } \\
\text { Coefficients }\end{array}$} & \multicolumn{2}{c}{$\begin{array}{c}\text { Std } \\
\text { Coefficients }\end{array}$} & \multicolumn{1}{c}{ t } & Sig. \\
& \multicolumn{1}{c}{ B } & Std. Error & \multicolumn{1}{c}{ Beta } & & \\
(Constant) & .065 & .082 & & .797 & .432 \\
PPP & 1.140 & .097 & .870 & 11.783 & .000 \\
ROA & -.308 & .248 & -.087 & -1.243 & .224 \\
CURRENT & -.015 & .007 & -.175 & -2.138 & .041 \\
DER & -.113 & .040 & -.253 & -2.799 & .009
\end{tabular}

a. Dependent Variable: SRD

Variabel kinerja lingkungan (PPP) memiliki nilai signifikansi $<0.05$ $(0.000<0.05)$ dan $\mathrm{t}$ hitung $>\mathrm{t}$ tabel (11.783 > 2.048) maka variabel PPP secara parsial mempunyai pengaruh yang signifikan terhadap pengungkapan laporan keberlanjutan (SRD). Hasil ini konsisten dengan penelitian Felicia dan Paskah (2014) yang menyatakan bahwa kinerja lingkungan (PPP) berpengaruh secara signifikan terhadap pengungkapan laporan berkelanjutan. Semakin baik kinerja lingkungan suatu perusahaan maka akan semakin banyak indikator yang akan diungkapkan dalam laporan keberlanjutan. Variabel profitabilitas (ROA) memiliki nilai $\mathrm{t}$ hitung $>-\mathrm{t}$ tabel $(-1.243>-2.048)$ maka secara parsial variabel ROA mempunyai pengaruh yang signifikan terhadap pengungkapan laporan keberlanjutan
(SRD). Nilai beta unstandardized coefficients ROA sebesar -0.308 penelitian ini sesuai dengan penelitian yang dilakukan oleh Mega (2013), yang menyatakan bahwa variabel profitabilitas ROA memiliki pengaruh negatif signifikan terhadap pengungkapan laporan keberlanjutan (SRD). Hal ini sesuai dengan teori legitimasi yang menyatakan bahwa pada saat perusahaan memiliki laba yang tinggi maka tidak perlu mengungkapkan hal-hal yang menganggu suksesnya laporan keuangan dan keberlanjutan perusahaan, sedangkan apabila tingkat laba rendah maka perusahaan akan memperbaiki kinerja perusahaan supaya pengguna laporan dapat membaca laporan tersebut dan dapat meningkatkan citra positif perusahaan.Variabel likuiditas (CURRENT) memiliki nilai 
signifikansi $<0.05(0.041<0.05)$ dan $\mathrm{t}$ hitung $>\mathrm{t}$ tabel $(-2.138>-$ 2.048) maka variabel CURRENT secara parsial mempunyai pengaruh yang signifikan terhadap pengungkapan laporan keberlanjutan (SRD). Hasil ini tidak konsisten dengan penelitian yang dilakukan oleh Mega (2014) yang menyatakan bahwa variabel likuiditas (CURRENT) tidak berpengaruh secara signifikan terhadap pengungkapan laporan keberlanjutan. Kesimpulan Uji Signifikansi Parameter Individual (t-test) menunjukkan bahwa variabel kinerja lingkungan (PPP) memiliki pengaruh yang positif signifikan terhadap pengungkapan laporan keberlanjutan (SRD), hasil penelitian ini sesuai dengan teori signalling yang menyatakan apabila Kementrian Lingkungan Hidup dan Badan Pengendalian Dampak Lingkungan (Bapedal) merilis hasil PROPER untuk perusahaan maka dapat meningkatkan kembali sinyal positif dari investor dan calon investor pada pengungkapan laporan keberlanjutan. Variabel profitabilitas (ROA), likuiditas (CURRENT) dan leverage (DER) memiliki pengaruh negatif signifikan terhadap pengungkapan laporan berkelanjutan (SRD), sesuai dengan teori stakeholder menyatakan bahwa para stakeholder memiliki kekuatan untuk mengendalikan atau mempengaruhi penggunaan sumber daya atau input yang digunakan dalam operasi. Stakeholder merupakan semua pihak baik pihak internal maupun eksternal perusahaan seperti pemerintah, perusahaan pesaing, masyarakat sekitar, lingkungan internasional, para pekerja, para pemerhati lingkungan dan lain sebagainya yang keberadaannya sangat mempengaruhi atau dipengaruhi oleh perusahaan. Sehingga para stakeholder merupakan pengguna laporan keuangan dan akan memperhatikan pengungkapan laporan keberlanjutan perusahaan. 


\section{KESIMPULAN}

Berdasarkan hasil uji dan pembahasan tersebut maka penulis dapat diambil beberapa kesimpulan di mana kinerja lingkungan yang diukur berdasarkan penilaian PROPER memiliki mengaruh yang signifikan terhadap pengungkapan laporan keberlanjutan. Hal ini dapat dilihat dari uji $\mathrm{F}$ dengan nilai signifikansi $0.000<0.05$ dan uji $t(t$ test) dengan nilai signifikansi 0.000 $<0.05$ serta nilai $\mathrm{t}$ hitung $>\mathrm{t}$ tabel (11.783 > 2.048). Semakin baik kinerja lingkungan yang dilakukan maka semakin baik peringkat PROPER dan pengungkapan laporan keberlanjutan. Kinerja keuangan berdasarkan sisi profitabilitas dengan menggunakan Ratio On Asset (ROA) memiliki pengaruh yang signifikan terhadap pengungkapan laporan keberlanjutan. Hal ini dapat dilihat dari uji $\mathrm{F}$ dengan nilai signifikansi $0.000<0.05$ dan uji $\mathrm{t}(\mathrm{t}$ test) dengan nilai $\mathrm{t}$ hitung $>-\mathrm{t}$ table $(-1.243>-$ 2.048). Semakin baik sisi profitabilitas perusahaan akan semakin baik perusahaan melakukan kinerja lingkungan dan semakin lengkap dalam mengungkapkan laporan keberlanjutan.
Kinerja keuangan berdasarkan sisi likuiditas dengan menggunakan Current Ratio memiliki pengaruh yang signifikan terhadap pengungkapan laporan keberlanjutan. Hal ini dapat dilihat dari uji $\mathrm{F}$ dengan nilai signifikansi $0.000<0.05$ dan uji $\mathrm{t}$ ( $\mathrm{t}$ test) dengan nilai signifikansi $0.041<0.05$. Semakin tinggi tingkat likuiditas perusahaan maka akan semakin baik dalam mengungkapkan laporan keberlanjutan. Kinerja keuangan berdasarkan sisi leverage dengan menggunakan Debt To Equity Ratio (DER) memiliki pengaruh yang signifikan terhadap pengungkapan laporan berkelanjutan. Hal ini dapat dilihat dari uji $\mathrm{F}$ dengan nilai signifikansi $0.000<0.05$ dan uji $\mathrm{t}$ ( $\mathrm{t}$ test) dengan nilai signifikansi $0.009<0.05$. Semakin rendah tingkat leverage perusahaan maka semakin baik dalam melakukan pengungkapan laporan keberlanjutan, sedangkan untuk keterbatasan dalam penelitian ini adalah tidak adanya ketentuan standar baku dalam menentukan indikator dalam pengungkapan laporan keberlanjutan yang berdasarkan GRI sehingga mengandung unsur subyektifitas dalam menentukan indeks tersebut.. 
Penelitian ini menggunakan penilaian yang bersifat kuantitatif sehingga dapat terjadi kesalahan dalam melakukan perhitungan. Penelitian ini menggunakan 33 sampel dari perusahaan yang

\section{DAFTAR PUSTAKA}

Adistira, Daniel (2013). Pengaruh

Karakteristik Perusahaan Terhadap Praktek Pengungkapan Sustainability Reporting Dalam Laporan Tahunan Perusahaan Publik di Indonesia, Jurnal Reviu Akuntansi dan Keuangan, ISSN : 2088-0685, Vol. 3, No. 1 April 2013.

Azwir, Elfi, dan Irna (2014).

Pengaruh Karakteristik Perusahaan dan Corporate Governance terhadap Pengungkapan Sustainability Report pada Perusahaan LQ45 yang Terdaftar, Jurnal Ekonomi Universitas Riau, Vol. 22, No. 1 Maret 2014.

Binus Business Review

Management, Accounting and Hospitality Management Vol.3 No.2 November 2014: 527-536

Brian D (2012). The Effect of

Corporate Sustainability Report on Firm Valuation, Claremont McKenna College, CMC Senior mendapat peringkat PROPER, go public dan menerbitkan laporan tahunan dari 2011-2013 serta berada di DKI jakarta, sampel yang digunakan sangat sedikit.

Theses, Page 489, December 2012.

Bursa Efek Indonesia (2014). Laporan Keuangan Perusahaan Nonkeuangan. Diakses 25 Desember 2014 dari http://www.idx.co.id.

Doupnik, Timothy; Perera, Hector. (2012). International Accounting, Third Edition. Singapore: McGrawHill.

Duwi Priyatno (2012). Belajar Analisis Data dengan SPSS 20. Yogyakarta: Andi. Environmental Performance

Ghozali, Imam (2011). Aplikasi Analisis Multivariate dengan Program SPSS. Edisi 7. Semarang: Badan Penerbit Universitas Diponegoro.

Gibson (2011), Financial statement Analysis, 12th Edition, Canada: South-Western Cengage Learning. 
Guthrie \& Abeysekera (2006).

Content Analysis of Social, Environmental Reporting:

What is new?: Journal of Human Resource Costing \& Accounting.University of Wollongong, Vol. 10, No. 2, 114-126.

Indra Sari, Hari (2013). Pengaruh

Sustaiability Reporting Terhadap abnormal Return Saham Pada Badan Usaha Sektor Pertambangan Yang Terdaftar Di BEI Pada Periode 2010-2012”, Jurnal Ilmiah Mahasiswa Surabaya Vol. 2 No 2.

Irham Fahmi (2013). Analisis

Laporan Keuangan.

Bandung: Alfabeta. 